\title{
Desensitizing Glutamate Receptors Shape Excitatory Synaptic Inputs to Tiger Salamander Retinal Ganglion Cells
}

\author{
Peter D. Lukasiewicz, Jean E. Lawrence, and Tony L. Valentino \\ Department of Ophthalmology and Visual Sciences and Department of Anatomy and Neurobiology, Washington \\ University School of Medicine, St. Louis, Missouri 63110-1093
}

\begin{abstract}
AMPA/kainate (KA) receptors mediate a component of ganglion cell excitatory postsynaptic currents (EPSCs). We investigated whether desensitization at these receptors contribute to the shape of transient EPSCs in ON-OFF ganglion cells. Whole-cell, voltage-clamp recordings were made from ganglion cells in the retinal slice or in isolation. EPSCs were evoked by either stimulating the slice with light or puffing $\mathrm{K}^{+}$at the outer plexiform layer (OPL). The AMPA/KA receptor-mediated component of the EPSCs was isolated by including NMDA receptor antagonists in the bath. Strychnine and picrotoxin blocked inhibitory inputs. In isolated ganglion cells, cyclothiazide (10 $\mu \mathrm{M})$, which blocks desensitization in non-NMDA receptors, enhanced both the amplitude and the duration of currents evoked by puffs of AMPA or glutamate. EPSCs evoked by $\mathrm{K}^{+}$-puffs in the OPL were also enhanced by cyclothiazide $(30 \mu \mathrm{M})$. When AMPA/KA receptors were blocked with NBQX (10 $\mu \mathrm{M})$, no enhancement of the EPSCs by cyclothiazide was observed, indicating that cyclothiazide did not act presynaptically. Cyclothiazide also enhanced the amplitude and duration of both the ON and OFF light-evoked (L-) EPSCs recorded in ON-OFF ganglion cells. Current-voltage relationships showed the enhancement was not voltage dependent. When control and enhanced responses where normalized, it was observed that the rate of desensitization of both the ON and OFF L-EPSCs was decreased by cyclothiazide. Cyclothiazide selectively enhanced the AMPA/ KA receptor-mediated component of ganglion cells EPSCs, suggesting that desensitization of AMPA/KA receptors shape transient L-EPSCs.
\end{abstract}

[Key words: cyclothiazide, AMPA-preferring receptors, AMPA/KA receptors, diazoxide, retinal slices, whole-cell patch clamp]

Light-evoked excitatory synaptic inputs to retinal ganglion cells are mediated by both NMDA and AMPA/KA ( $\alpha$-amino- 3 -hydroxy-5-methyl-4-isoxazolepropionate/kainate) glutamate receptors in salamanders (Lukasiewicz and McReynolds, 1985; Mitt-

\footnotetext{
Received Jan. 31, 1995; revised Apr. 5, 1995; accepted May 9, 1995.

We thank Paul Cook, John McReynolds, and Carmelo Romano for comments on the manuscript and Eli Lily and Co. for the gift of cyclothiazide. This work was supported by NIH Grants EY08922 (P.D.L.), T32-EY07057 (T.L.V.), and EY02687, a Core Grant to the Department of Ophthalmology, a Research to Prevent Blindness Miriam and Benedict Wolf Scholars $\Lambda$ ward (P.D.L.), and a Mr. and Mrs. Spencer T. Olin Fellowship (J.E.L.).

Correspondence should be addressed to Dr. Peter D. Lukasiewicz, Department of Ophthalmolngy and Visual Sciences, Washington University School of Medicine, St. Louis, MO 63110-1093.

Copyright 01995 Society for Neuroscience $0270-6474 / 95 / 156189-11 \$ 05.00 / 0$
}

man et al., 1990; Diamond and Copenhagen, 1993; but see Coleman and Miller, 1988), rabbits (Massey and Miller, 1988, 1990), cats (Boos et al., 1990), and primates (Cohen and Miller, 1994). AMPA/KA receptors are responsible for the rapidly activating and -inactivating component of excitatory synaptic inputs in many neurons (Dale and Roberts, 1985; Forsythe and Westbrook, 1988; Hestrin et al., 1990; Mittman et al., 1990). These desensitizing glutamate receptors have been shown to play a role in shaping the synaptic responses in the CNS (Trussell et al., 1993; Larson et al., 1994; Pelletier and Hablitz, 1994; Rammes et al., 1994). The role that desensitizing, AMPA/KA receptors play in forming ganglion cell responses is unknown.

AMPA/KA glutamate receptors are known to exist in a variety of molecular forms (Sommer and Seeburg, 1992). Expression studies have demonstrated that AMPA/KA receptors exist as either AMPA- (Boulter et al., 1990; Keinänen et al., 1990) or kainate-preferring (Bettler et al., 1990; Egebjerg et al., 1991; Werner et al., 1991; Bettler et al., 1992) receptors. AMPA-preferring receptors predominate on hippocampal neurons whereas kainate-preferring receptors predominate on dorsal root ganglion neurons (Kiskin el al., 1986; Huetlner, 1990; Wong and Mayer, 1993). The kinetics of the currents mediated by AMPA-preferring receptors depend on the agonist. Glutamate, AMPA, and quisqualate mediate rapidly desensitizing currents while kainate mediates relatively sustained currents (Trussell et al., 1988; Tang et al., 1989).

Recent studies have shown that lectins (Mayer and Vyklicky, 1989; O'Dell and Christensen, 1989; Huettner, 1990) and thiazides (Yamada and Rothman, 1992; Yamada and Tang, 1993; Trussell et al., 1993; Zorumski et al., 1993) potentiate responses by reducing or blocking the desensitization of AMPA/KA receptors. Thiazides selectively augment responses mediated by AMPA-preferring receptors whereas lectins strongly potentiate responses mediated by kainate-preferring receptors but only weakly enhance responses mediated by AMPA-preferring receptors (Partin et al., 1993; Wong and Mayer, 1993).

ON-OFF ganglion cells in the salamander retina respond to sustained light stimuli with transient voltage responses at light onset and offset (Werblin and Dowling, 1969). The mechanisms by which these transient responses are generated are unknown. The formation of some transient amacrine cell responses may be due to presynaptic inhibitory inputs at bipolar terminals producing transient transmitter release (Werblin et al., 1988; Maguire et al., 1989). We investigated whether the postsynaptic, desensitizing, AMPA/KA receptor plays a role in the establishment of transient light responses in ON-OFF ganglion cells.

We show that thiazides enhanced both the amplitude and the 
duration of both light-evoked and $\mathrm{K}^{+}$puff-elicited EPSCs mediated by AMPA/KA receptors, but not those mediated by NMDA receptors. Thiazides also enhanced currents evoked by AMPA/KA receptor agonists in isolated ganglion cells. These findings demonstrate that the thiazides acted postsynaptically to augment the EPSCs and suggests that desensitizing, AMPA/KA receptors shape the transient responses in ON-OFF ganglion cells. The thiazide sensitivity of $\Lambda \mathrm{MP} \Lambda / \mathrm{K} \Lambda$ receptors on $\mathrm{ON}$ OFF ganglion cells indicates that these receptors are predominately the AMPA-preferring subtype.

\section{Materials and Methods}

Whole-cell patch recording in retinal slices. Whole-cell patch recordings (Hammill et al., 1981) were made from ganglion cells in retinal slice preparations (Werblin, 1978). The recording procedures have been described in detail elsewhere (Barnes and Werblin, 1986, 1987; Lukasiewicz and Werblin, 1994; Lukasiewicz and Roeder, 1995).

Procedures for labeling and isolating ganglion cells. To distinguish ganglion cells from other retinal neurons in isolation, we labeled ganglion cells by injecting the optic nerve with rhodamine B isothiocyanate. Salamanders were anesthetized by placing them in a room temperature water bath containing $0.06 \%$ MS-222 (tricane methane sulfonate) (Sigma, St. Louis, MO). During surgery, the animals were kept in an ice water bath containing MS-222. A $1.5 \mathrm{~cm}$ incision was made over the optic nerve and the overlying tissue was removed. The optic nerve was exposed by cutting the surrounding sheath with iris scissors. The uncovered optic nerve was impaled with a microelectrode containing $4 \%$ rhodamine B isothiocyanate (Sigma, St. Louis, MO) dissolved in $10 \%$ DMSO and $90 \%$ salamander Ringer's (see below). The injections were made with a Picospritzer (General Valve Corp., Fairfield, NJ). After the injections, gentamicin drops ( $4 \mathrm{mg} / \mathrm{ml}$ ) (Sigma, St. Louis, MO) were placed in the operated area and the incision was sutured. The animals recovered from surgery in aerated pond water that contained $3000 \mathrm{U} / \mathrm{liter}$ of penicillin and $3 \mathrm{mg} / \mathrm{liter}$ of streptomycin (Sigma, St. Louis, MO). Animals were maintained for 3-5 d before sacrifice.

Ganglion cells were isolated using methods similar to Gilbertson et al. (1991). Briefly, dissociations were performed by incubating the isolated retina for $30 \mathrm{~min}$ at $30^{\circ} \mathrm{C}$ with $7-15 \mathrm{U}$ of papain (Worthington, Freehold, NJ) per milliliter of dissociation solution (Gilbertson et al., 1991). The retina was then rinsed at least three times with rinse solution (Gilbertson et al., 1991) and gently triturated with a fire polished Pasteur pipette. The dissociated retinal cells were plated on cover glass which was coated with $1 \%$ 3-aminopropyl-triethoxy-silane (Sigma, St. Louis, $\mathrm{MO}$ ) and allowed to adhere at room temperature for $15 \mathrm{~min}$. Rhodamine-labeled ganglion cells were viewed using a Nikon mercury fluorescent epiilluminator with a Nikon G1-B filter set. Observations of retinal slices made from eyes backfilled with rhodamine showed that only cells in the ganglion cell layer were labeled. This indicates that rhodaminc-labeled isolated cells were most likely ganglion cells.

Electrode and bathing solutions. The intracellular electrode solution (Mittman et al., 1990) consisted of (in mM): cesium fluoride, 90.5; sodium chloride, 3.4; magnesium chloride, 0.4; calcium chloride, 0.4 ; EGTA, 11; and sodium HEPES, 10; adjusted to $\mathrm{pH} 7.7$ with cesium hydroxide (the free calcium concentration was $10^{-9} \mathrm{M}$ ). Fluoride greatly enhanced the probability of obtaining high quality seals and had no effect on ganglion cell EPSCs recorded in control bathing solution (Mittman et al., 1990; Diamond and Copenhagen, 1993; Lukasiewicz and Werblin, 1994). The bathing medium (salamander Ringer) contained (in $\mathrm{mM}$ ): sodium chloride, 112; potassium chloride, 2; calcium chloride, 2; magnesium chloride, 1; glucose, 5; and HEPES, 5; adjusted to $\mathrm{pH} 7.8$ with $\mathrm{NaOH}$. Unless otherwise indicated, all chemicals were obtained from Sigma Chemical (St. Louis, MO). AMPA, CNQX (6cyano-7-nitroquinoxaline-2,3-dione), and the NMDA receptor antagonists D-2-amino-5-phosphonopentanoic acid (D-AP5) and ( \pm )-2-amino7-phosphonoheptanoic acid (AP7), were obtained from Research Biochemicals International (Natick, MA). The NMDA receptor channel blocker MK801 was kindly provided by Dr. Carmelo Romano (Washington University, St. Louis), NBQX (6-nitro-7-sulfamoylbenzo(f)quinoxaline-2,3-dione) was kindly provided by Dr. Madelon Price (Washington University, St. Louis), and cyclothiazide was provided by the Lilly Research Laboratories (Indianapolis, IN). Experiments were performed at room temperature $\left(20-24^{\circ} \mathrm{C}\right)$.

The control bathing solution used in our slice experiments was for- mulated to pharmacologically isolate the ganglion cell EPSCs. GABAergic and glycinergic inhibitory synaptic inputs were blocked with picrotoxin $(150 \mu \mathrm{M})$ and strychnine $(2 \mu \mathrm{M})$, respectively (Belgum et al., 1984; Lukasiewicz and Werblin, 1990; Mittman et al., 1990; Diamond and Copenhagen, 1993). Voltage-gated sodium currents were blocked by including $0.5 \mu \mathrm{M}$ tetrodotoxin in the bath, and voltage-gated potassium currents were blocked by including cesium in the recording electrodes (Lukasiewicz and Werblin, 1988).

Antagonists and modulators were applied locally over a relatively large area of the slice under study (several millimeters in width) by a gravity-driven superfusion system at a rate of $1-2 \mathrm{ml} / \mathrm{min}$. Fine PE tubings from ten $10 \mathrm{ml}$ syringes were fastened inside a plastic micropipette tip. The pipette tip ( $400 \mu \mathrm{m}$ inner diameter) was placed at least $1 \mathrm{~mm}$ from the slice. Solutions flowed from the ganglion cell side to the photoreceptor side of the slice. In addition to the local drug application, the entire recording chamber was continually superfused with control Ringer's at a rate of $1-2 \mathrm{ml} / \mathrm{min}$ to accelerate washout of the applied drugs.

Agonist puffing onto isolated ganglion cells. Glutamate agonists were puffed onto the cell bodies and/or dendrites of isolated ganglion cells with a Picospritzer (General Valve Corp., Fairfield, NJ). The rate of puffed drug delivery was presumably slow compared to a more rapid drug application system (Raman and Trussell, 1992) and probably led to an underestimate of the number of cells with rapidly desensitizing responses (Trussell et al., 1988). Sustained puff applications often resulted in lost recordings when the puff dislodged the cell from the recording pipette. Consequently, we chose a puff duration and pressure that would maximize the rate of agonist delivery and minimize the loss of recordings.

Puffing potassium at the bipolar dendrites. Synaptically driven responses in ganglion and amacrine cells were elicited by "puffing" po-

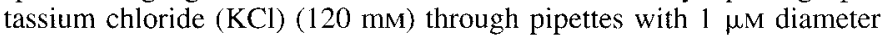
tips onto bipolar cell dendrites (Lukasiewicz and Werblin, 1994). The details of this methodology are described in Lukasiewicz and Roeder (1995).

Light stimulation. The light stimulus apparatus and procedures were identical to those described in Lukasiewicz and Roeder (1995). Briefly, the light source was a tungsten halogen lamp $(20 \mathrm{~W})$ (Ealing ElectroOptics, Holliston, MA). Full-field, white light stimuli were used. The intensity of the unattenuated light stimulus was equivalent to $3.6 \times 10^{16}$ quanta $/ \mathrm{cm}^{2} / \mathrm{sec}$ of a monochromatic light of $500 \mathrm{~nm}$.

For light stimulation experiments, the dissections and preparation of the slices were performed under dim red illumination. Infrared viewers (Electrophysics Corp., Nutley, NJ) were used to view the slices under infrared illumination during the recording procedures.

Liquid junction potential correction. Membrane potential values given in this article were corrected for junction potentials. Liquid junction potentials were determined as described by Fenwick et al. (1982). They were typically $-6 \mathrm{mV}$ for the cesium fluoride (CsF) electrode solution.

Cell identification. In the slice preparation, ganglion cells were identified by their characteristic current responses to light stimuli (Mittman et al., 1990). More than $90 \%$ of ganglion cells recorded in the slice preparation were ON-OFF cells that responded with transient EPSCs at light onset and offset. The remaining cells were ON cells that responded with a sustained EPSC to the light stimulus. Almost all of the results reported here were obtained from ON-OFF ganglion cells. Some cells were stained by including Lucifer yellow $\mathrm{CH}(0.25 \%)$ (Aldrich Chemicals, Milwaukee, WI) in the electrode (Stewart, 1978). Cells and processes were viewed using a Nikon mercury fluorescent epiilluminator with an Omega Optical XF15 filter set (Brattleboro, VT). Ganglion cell subtypes were identified by the ramification of their dendrites at different depths in the inner plexiform layer (IPL) (Famiglietti et al., 1977; Nelson et al., 1978).

Recording system. The microscope system and patch-clamp apparatus used for this study were described in Lukasiewicz and Roeder (1995). Electrodes were pulled from borosilicate glass (TW150F-4, W.P.I., Sarasota, FL) with a Sachs-Flaming puller (Sutter Instruments, Novato, CA) and had measured resistances of less than $5 \mathrm{M} \Omega$. The measured series resistances were typically 15-25 M $\Omega$. The magnitude of the series resistance compensation, read off of the Dagan 3900A compensation counting dial, was 5-10 M $\Omega$. pCLAMP software (Axon Instruments, Foster City, CA) was used to generate voltage command outputs, acquire data and trigger the Picospritzer. The data were digitized and stored with a $33 \mathrm{MHz} 386-\mathrm{PC}$ using a Labmaster DMA data acquisition board (Scientific Solutions, Solon, OH). Responses were filtered at 2 
A

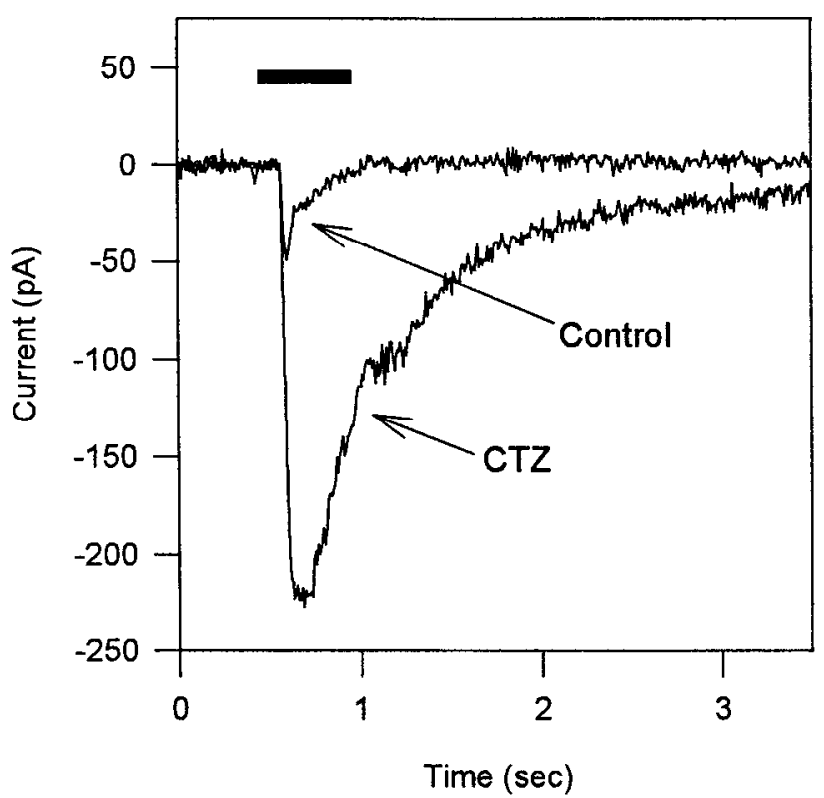

B Normalized Responses

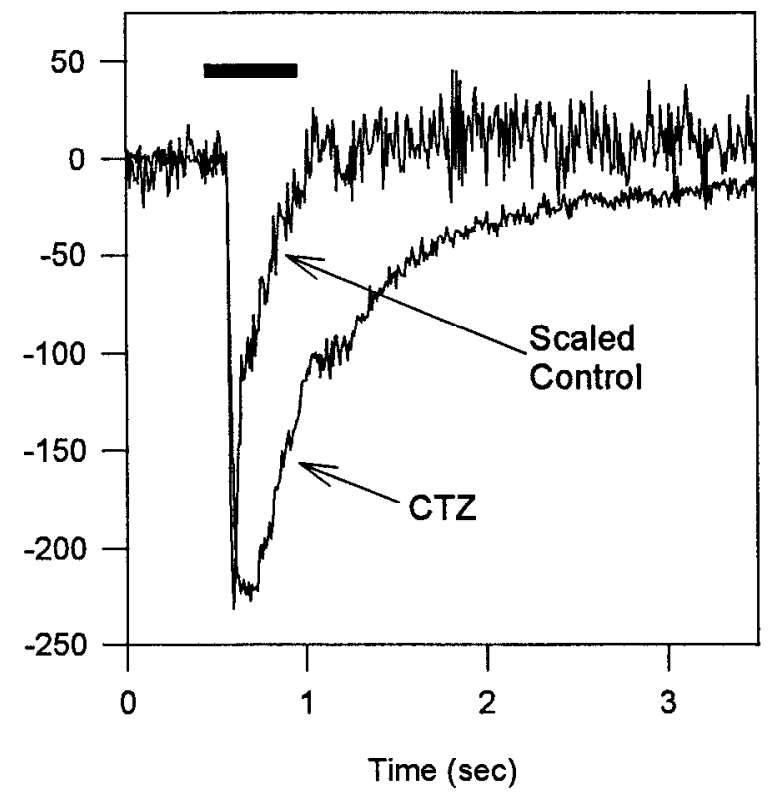

Figure 1. Cyclothiazide enhanced glutamate currents in isolated ganglion cells. $A$, The current responses recorded in the absence and presence of $10 \mu \mathrm{M}$ cyclothiazide are labeled control and $\mathrm{CTZ}$, respectively. Cyclothiazide enhanced the control current almost fivefold. $B$, The control current was scaled to the peak of the cyclothiazide-enhanced current for comparison (scaled control). The scaled control current had a faster rate of desensitization than the enhanced current (see text). The time course of the puff was 441 msec in duration and is indicated by the trace above the current responses in this and the succeeding figures. The concentration of glutamate in the puff pipette was $10 \mathrm{~mm}$. The cell was voltage clamped to $-75 \mathrm{mV}$. Each current trace is the average of three to five responses in this and the subsequent figures.

$\mathrm{kHz}$ with the four pole Bessel low pass filter on the Dagan 3900A and sampled at $100 \mathrm{~Hz}$. Data were analyzed using Clampan (Axon Instruments, Foster City, CA). Results are expressed as mean values \pm 1 standard deviation.

\section{Results}

Thiazides enhance glutamate agonist currents in isolated retinal ganglion cells

In order to determine if the thiazide compounds were acting directly on ganglion cells in the retinal slice preparation we first ascertained their effects on glutamate currents in isolated ganglion cells. Figure $1 A$ shows a current response to a puff of glutamate $(10 \mathrm{mM})$. When the cell was clamped to $-75 \mathrm{mV}$, glutamate elicited an inward current that activated rapidly and then desensitized during the continued presence of glutamate. The amplitude of the current decayed to $7 \%$ of the maximum amplitude by the end of the puff stimulus. Rapid desensitization was observed in 16 out of 19 cells. In the remaining three cells the glutamate currents were relatively sustained and decayed very slowly. The difference in the rates of desensitization observed could reflect either variable kinetics of the glutamate puff application or different complements of AMPA- or kainate-preferring receptor types on different ganglion cells (see introductory section). The glutamate responses were most likely mediated by AMPA/KA receptors because none of our isolated cells responded to puffs of NMDA (1 mM). Also, the current-voltage relationships for the glutamate-evoked responses were always linear when $1 \mathrm{mM} \mathrm{MgCl}_{2}$ was present in the bath, indicating that NMDA receptors did not contribute to these responses. Others have also reported (Akaike et al., 1988; Chizhmakov, 1989; Huettner, 1990) that when CNS neurons were acutely isolated with papain their responsiveness to NMDA was reduced.
When glutamate was puffed in the presence of $10 \mu \mathrm{M} \mathrm{cy-}$ clothiazide, both the magnitude and the duration of the glutamate current were increased (Fig. 1A). The peak amplitude of this cell was enhanced 4.7-fold. Upon wash out of cyclothiazide both the magnitude and the duration of the current returned to control values (data not shown). For seven cells, the mean enhancement was $3.77 \pm 1.64$-fold. When $30 \mu \mathrm{M}$ cyclothiazide was used, the mean enhancement was increased to $21.97 \pm 13.7$ fold $(n=11)$. Similar results have been reported with isolated hippocampal neurons (Yamada and Rothman, 1992; Yamada and Tang, 1993; Zorumski et al., 1993) and with isolated patches from auditory neurons (Trussell et al., 1993).

To determine if the effect of cyclothiazide was due to a reduction in the rate of desensitization of the receptors, the time course of the decay of the control current was compared to the time course of the decay of the cyclothiazide-enhanced current. Figure $1 B$ shows that when the control current was scaled to the same amplitude as the enhanced current, the current recorded in the presence of $10 \mu \mathrm{M}$ cyclothiazide desensitized nearly ten times more slowly than the control current. The time for decay to half of the maximal current $\left(T^{1 / 2}\right)$ was $45 \mathrm{msec}$ for the control current and $423 \mathrm{msec}$ for the thiazide-enhanced current. The mean enhancement for the decay to $T^{1 / 2}$ was $8.4 \pm 6$-fold ( $n=$ 6). These data indicate that cyclothiazide reduced the rate of desensitization of AMPA/KA receptors on isolated ganglion cells. In two additional cells, the rate of decay of the glutamate response was not enhanced by cyclothiazide, suggesting that a different subtype of AMPA/KA receptor predominated on these cells (see below).

In ganglion cells, responses to puff applications of the AMPA/ $\mathrm{KA}$ receptor agonists AMPA and kainate were both potentiated 
A

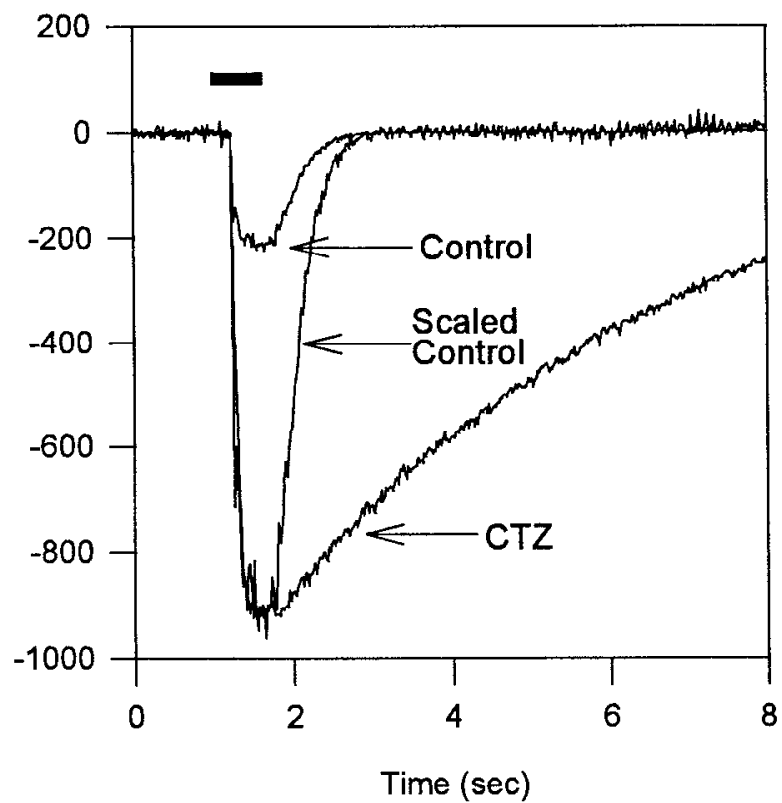

B

Kainate

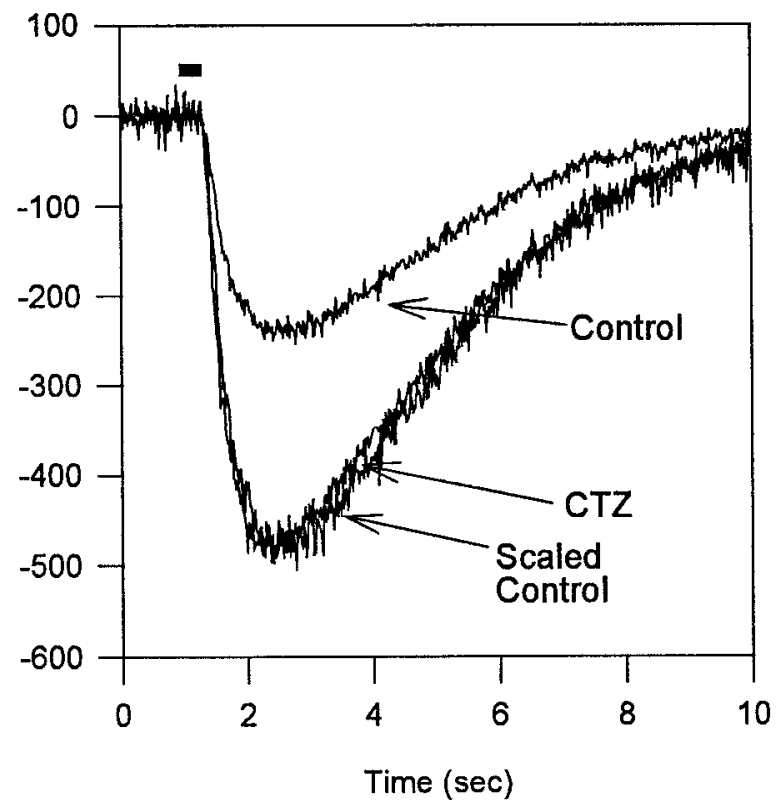

Figure 2. The effects of cyclothiazide on AMPA- and kainate-elicited currents recorded from isolated ganglion cells. A, Cyclothiazide (10 $\mu$ M) enhanecd both the amplitude and the duration of the control AMPA-cvoked current. The concentration of AMPA in the puffer was $100 \mu \mathrm{M}$. The scaled control current decayed more rapidly than the cyclothiazide-enhanced current $(C T Z)$. $B$, Kainate currents recorded in the absence and presence of $10 \mu \mathrm{M}$ cyclothiazide. The amplitude of the kainate current was enhanced by cyclothiazide. The concentration of kainate in the puffer was 100 $\mu \mathrm{M}$. The scaled control current desensitized at the same rate as the cyclothiazide-enhanced current. The cells were voltage clamped to $-75 \mathrm{mV}$.

by cyclothiazide. Figure 2 compares the current responses to puffs of AMPA and kainate onto isolated ganglion cells. For the AMPA-elicited currents, both the amplitudes and the durations were enhanced by cyclothiazide (Fig. $2 A$ ). The rate of the AMPA current desensitization was reduced by cyclothiazide (10 $\mu M)$. This can be seen by comparing the cyclothiazide-enhanced current with the scaled control current in Figure $2 A$. The $T 1 / 2$ for decay was increased by cyclothiazide from $0.51 \mathrm{sec}$ for the control current to $3.44 \mathrm{sec}$. For six cells studied, cyclothiazide enhanced the amplitude of the AMPA-evoked currents $4.9 \pm 0.9$ fold and increased the $T \frac{1}{2}$ for decay $8.6 \pm 6.4$-fold.

Figure $2 B$ shows that kainate-induced currents were also potentiated by cyclothiazide. In contrast to the AMPA currents, only the amplitude and not the duration was enhanced by cyclothiazide. The cyclothiazide-enhanced kainate currents and the scaled-control currents had nearly identical time courses. In three cells studied, kainate enhanced the amplitude $2.3 \pm 0.4$ fold and increased the $T \frac{1}{2}$ for decay $1.3 \pm 0.4$-fold. Patneau et al. (1993) reported similar enhancements of kainate-evoked currents by cyclothiazide in isolated hippocampal neurons. Their results showed that kainate-evoked currents did desensitize, but, in the absence of cyclothiazide, it was too rapid to be measured by whole-cell recordings. In ganglion cells, the enhancement of the kainate-evoked currents by cyclothiazide is probably also do to the blockade of rapid desensitization.

\section{AMPA/KA receptor-mediated excitatory synaptic inputs were enhanced by thiazides}

Although we have shown that glutamate- and AMPA-evoked currents were enhanced by cyclothiazide in dissociated ganglion cells, it is not clear whether the thiazide-sensitive receptors me- diate synaptic responses in the slice preparation. To determine the effects of thiazides on ganglion cell EPSCs, excitatory synaptic inputs were elicited by exciting bipolar cells with focal puffs of potassium. Bipolar cells were depolarized with potassium rather than glutamate to bypass AMPA/KA receptors in the outer plexiform layer that may have been affected by the thiazides. The thiazides diazoxide and cyclothiazide have both been shown to enhance synaptic responses in chicken cochlear nuclear neurons (Trussell et al., 1993) and cultured rat hippocampal neurons (Yamada and Rothman, 1992; Yamada and Tang, 1993). NMDA receptors were blocked by including $1 \mu \mathrm{M}$ MK-801 in the bathing solution. Figure 3 shows the AMPA/KA receptor-mediated component of an EPSC evoked by an OPL$\mathrm{K}^{+}$puff. Bath-applied diazoxide $(500 \mu \mathrm{M})$ enhanced both the amplitude and the duration of the EPSC (Fig. 3A). Diazoxide increased the peak amplitude 1.6-fold. Comparison of the timc courses of the normalized synaptic responses measured in the absence and presence of diazoxide showed that diazoxide reduced the rate of desensitization of the EPSC. The scaled control EPSC decayed with a $T^{1 / 2}$ of $95 \mathrm{msec}$ and the diazoxide-enhanced response decayed with a $T 1 / 2$ of $369 \mathrm{msec}$. For nine cells, diazoxide enhanced the peak amplitude of the EPSCs $3.5 \pm 1.3$ fold and increased $T \frac{1}{2}$ for decay $2.6 \pm 0.9$-fold.

Cyclothiazide was more potent than diazoxide in potentiating the AMPA/KA receptor-mediated component of the EPSC evoked by $\mathrm{K}^{+}$-puffs. We found that $30 \mu \mathrm{M}$ cyclothiazide was about as effective as $500 \mu \mathrm{M}$ diazoxide. The greater potency of cyclothiazide has also been described by Yamada and Tang (1993) in cultured rat hippocampal neurons. The highest effective dose of cyclothiazide from which we could get reasonable recovery was $30 \mu \mathrm{M}$. When we used $100 \mu \mathrm{M}$ cyclothiazide, a 

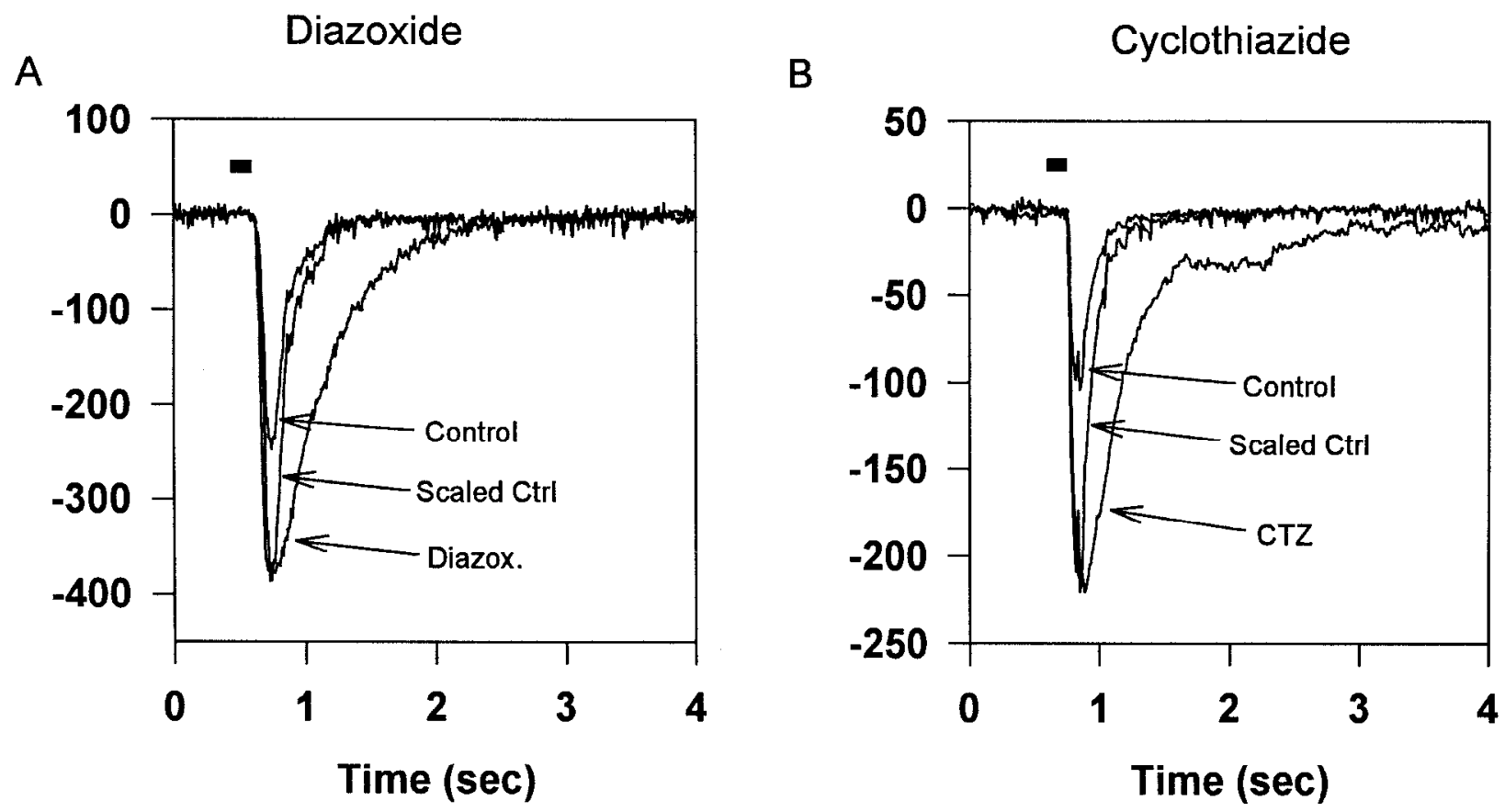

Figure 3. Thiazides enhanced the AMPA/KA receptor-mediated component of EPSCs evoked by OPL potassium puffs. A, Ganglion cell EPSCs recorded in the absence and presence of diazoxide $(500 \mu \mathrm{M})$. Both the amplitude and the duration of the EPSCs were enhanced. The scaled control desensitized more rapidly than the diazoxide-enhanced EPSC (Diazox.). B, Ganglion cell EPSCs recorded in the absence and presence of cyclothiazide $(30 \mu \mathrm{M})$. The EPSCs were cnhaneed by cyclothiazide $(C T Z)$. Comparison of the scaled control to the cyclothiazide-enhanced EPSC indicated that the rate of desensitization was slowed by the thiazide. The cells were voltage clamped to $-75 \mathrm{mV}$. For these experiments, and those illustrated in all of the subsequent figures, the control bathing solution containing $150 \mu \mathrm{M}$ picrotoxin, $2 \mu \mathrm{M}$ strychnine, and $0.5 \mu \mathrm{M}$ TTX was used to pharmacologically separate the EPSCs. The AMPA/KA receptor-mediated EPSCs were isolated by including $1 \mu \mathrm{M}$ MK-801 in the bath.

concentration reported to be maximally effective (Patneau et al., $1993)$, it was found to be no more effective than $30 \mu \mathrm{M}(1.02$ \pm 0.08 -fold, $n=4$ ). Also, at the higher concentration washout of the drug was very slow and cells were usually lost before recovery occurred.

Figure $3 B$ shows that cyclothiazide enhanced the amplitude of the $\mathrm{K}^{+}$-puff-evoked EPSP 2.2 -fold and the $T 1 / 2$ of decay was increased from 84 to $264 \mathrm{msec}$. In 16 cells tested, the EPSC amplitudes were enhanced $2.5 \pm 1.8$-fold, indicating that the glutamate receptors that mediate ganglion cell EPSCs may have been desensitized in the slice preparation. The decay $T 1 / 2$ values were also prolonged by $2.3 \pm 0.9$-fold (range 1.4-4.5-fold, $n=$ 16). This indicates that the decay of the EPSCs were determined, in part, by the desensitizing properties of the ganglion cell AMPA/KA receptors. The enhancement by $30 \mu \mathrm{M}$ cyclothiazide may have been less in the slice than in the isolated ganglion cells due to diffusion barriers (Larson et al., 1994) or uptake of the drug due to its lipid solubility (Pelletier and Hablitz, 1994).

The EPSC enhancement by thiazides was not voltage dependent. Figure $4 A$ shows the AMPA/KA receptor-mediated component of EPSCs recorded when the cell was clamped to a series of membrane potentials. The NMDA receptors were blocked by including $50 \mu \mathrm{M} \mathrm{AP7} \mathrm{in} \mathrm{the} \mathrm{bath.} \mathrm{The} \mathrm{EPSCs} \mathrm{were} \mathrm{enhanced}$ by cyclothiazide at both negative and positive holding potentials (Tig. $4 B$ ). The current-voltage relation shown in Figure $4 C$ was obtained by plotting the mean peak EPSC amplitudes for a population of ganglion cells versus holding potential. In both the absence and presence of cyclothiazide the current-voltage relations were linear. Cyclothiazide increased the synaptically evoked conductance 3.2-fold. In addition, the reversal potential was not altered by cyclothiazide, indicating that cyclothiazide did not enhance the response by altering the ionic selectivity of the AMPA/KA channels.

To ensure that cyclothiazide was not enhancing the EPSCs by unmasking other transmitter-gated channels, we showed that there was no residual current when the AMPA/KA receptors were blocked with antagonists. Figure 5 shows that when a $\mathrm{K}^{+}$ puff-evoked EPSC was enhanced by cyclothiazide, the enhanced response was completely blocked by $10 \mu \mathrm{M}$ NBQX. The NMDA receptors were blocked by including $50 \mu \mathrm{M}$ D-AP7 in the ball. Upon washout of the NBQX, the response recovered (data not shown). Similar results were obtained in five additional ganglion cells. These results agree with those reported by others (Yamada and Rothman, 1992; Yamada and Tang, 1993) for EPSCs recorded in cultured hippocampal neurons.

\section{Thiazides do not act presynaptically to enhance AMPA/KA receptor-mediated EPSCS}

Although the results from isolated cells show that cyclothiazide acts postsynaptically on ganglion cells, any presynaptic effects of cyclothiazide might also contribute to the total effect seen in the slice preparation. To test whether any of the effects seen in the slice preparation were due to an additional, presynaptic action of cyclothiazide, we tested the ability of cyclothiazide to enhance the NMDA receptor-mediated component of the ganglion cell EPSC. The AMPA/KA receptors were blocked by including NBQX $(10 \mu \mathrm{M})$ in the bath. Figure 6 shows that the NMDA receptor-mediated component of the response was not enhanced when $30 \mu \mathrm{M}$ cyclothiazide was present in the bath. In contrast to its enhancing effect on the AMPA/KA receptor-mediated component of the EPSC, the NMDA receptor-mediated component of the EPSC was slightly decreased by cyclothiazide. 

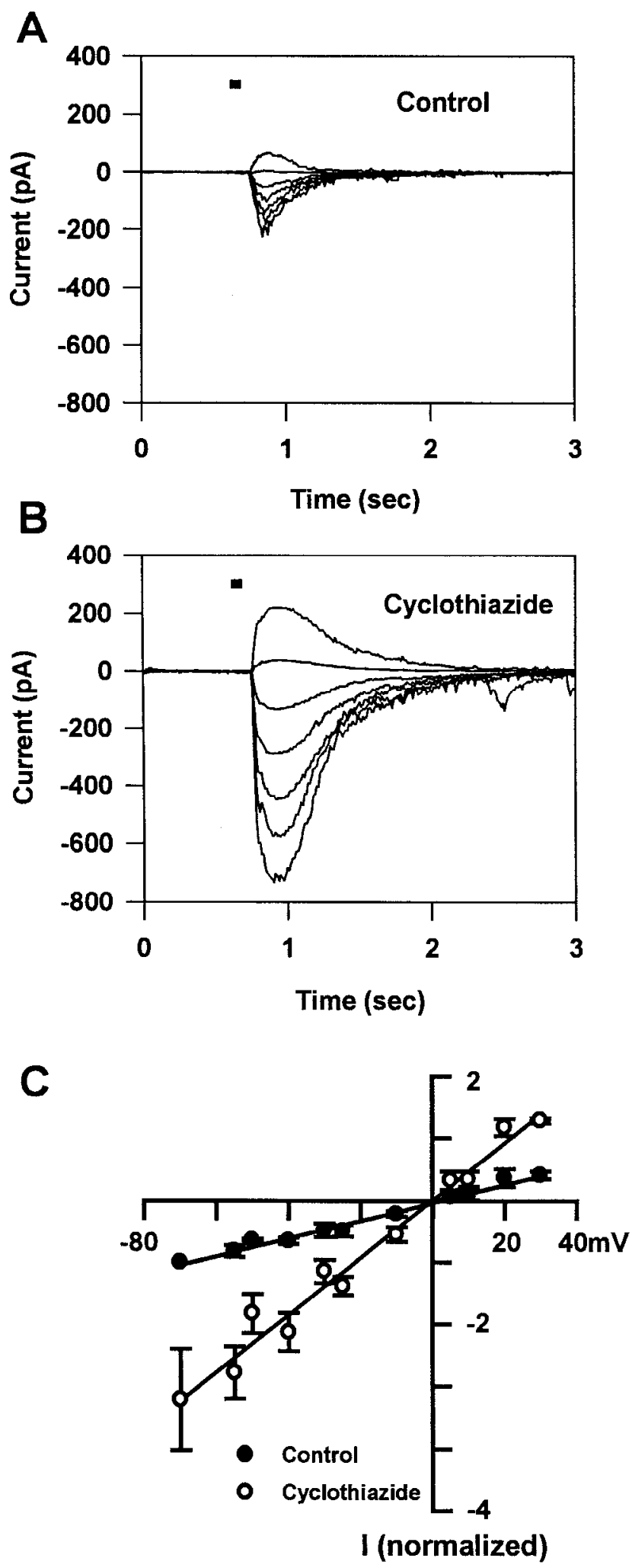

Figure 4. Current-voltage relationships for EPSCs evoked by OPL $\mathrm{K}^{+}$puffs in the absence and presence of cyclothiazide. $A$, Control EPSCs recorded in the absence of cyclothiazide when the cell was held at $-70,-55,-40,-25,-10,5$, and $20 \mathrm{mV}$. The currents were inward when the cell was held at negative potentials and outward when the cell was held at positive potentials. $B$, In the presence of cyclothiazide, the EPSCs were enhanced at each holding potential (as in $A$ ). Similar to the control responses, the enhanced currents also reversed polarity near $0 \mathrm{mV}$. $C$, Normalized current-voltage relations constructed from mea-
In the presence of cyclothiazide, the mean for the peak amplitude of the NMDA receptor-mediated component of the response was $86 \pm 5 \%(n=6)$ of the control. These results and those obtained with isolated cells are consistent with cyclothiazide acting postsynaptically at AMPA/KA receptors to enhance the excitatory synaptic responses.

\section{Light-evoked EPSCs were enhanced by cyclothiazide}

We have demonstrated that cyclothiazide potentiates the AMPA/ KA receptor-mediated component of OPL $\mathrm{K}^{+}$-puff evoked ganglion cell EPSCs. The duration of the responses were enhanced by reducing the rate of desensitization of the AMPA/KA receptors. We wanted to determine if the desensitization of nonNMDA receptors contributes to the transientness of the lightevoked EPSCs (L-EPSCs) in ON-OFF ganglion cells. Figure $7 A$ shows the AMPA/KA receptor-mediated components of $\mathrm{ON}$ and OFF L-EPSCs recorded from an ON-OFF ganglion cell that was voltage clamped to $-75 \mathrm{mV}$. The NMDA receptors were blocked by including 30-50 $\mu \mathrm{M}$ AP7 in the bath. In the presence of cyclothiazide, the amplitudes of both the $\mathrm{ON}$ and the $\mathrm{OFF}$ L-EPSCs were enhanced (2.5-fold and 2.4-fold, respectively). For the $10 \mathrm{ON}-\mathrm{OFF}$ cells tested, the mean enhancements were $4.0 \pm 1.5$-fold for the ON L-EPSCs and 5.1 \pm 2.5 -fold for the OFF L-EPSCs. The durations of the ON and OFF L-EPSCs were also prolonged by cyclothiazide. During the light step, the control ON EPSC rapidly returned to the dark current level. By contrast, the cyclothiazide-enhanced ON EPSC was still apparent at the end of the light step. When the control light response was normalized to the peak of the cyclothiazide-enhanced response so that the rates of desensitization of the light-evoked EPSCs can be compared (Fig. $7 B$ ) it could be seen that cyclothiazide decreased the rates of desensitization of both the $\mathrm{ON}$ and the OFF L-EPSCs; the $T 1 / 2$ values were increased 4.75 -fold and 2.15 -fold, respectively. Cyclothiazide was usually more effective at slowing the rate of decay of the ON L-EPSCs compared to the OFF L-EPSCs. For ten cells, cyclothiazide increased the $T 1 / 2$ for the ON L-EPSCs was increased $2.9 \pm 1.2$-fold and that of the OFF L-EPSCs by $2.1 \pm 0.4$-fold.

The voltage dependency of the cyclothiazide enhancement of light evoked EPSCs was investigated by eliciting responses when the cell was held at different potentials. Figure $8 \mathrm{~A}$ shows two families of light responses recorded from the same cell in the absence (thick traces) and presence (thin traces) of cyclothiazide. NMDA receptors were blocked by including $50 \mu \mathrm{M}$ AP7 in the bath. The ON and OFF L-EPSCs were largest when the cell was held at $-80 \mathrm{mV}$. The responses decreased when the cell was held at less negative potentials and reversed polarity when held at $20 \mathrm{mV}$. Cyclothiazide $(30 \mu \mathrm{M})$ enhanced the ON and OFF L-EPSCs at all holding potentials.

The effects of cyclothiazide upon ganglion cell L-EPSCs are more easily interpreted in the ON pathway because, in contrast

\section{$\leftarrow$}

surements made in the absence (solid circles) and presence (open circles) of $30 \mu \mathrm{M}$ cyclothiazide. Cyclothiazide enhanced peak amplitudes of EPSCs at all holding potentials. The solid lines are the best least squares fits of the data. The mean enhancement of the conductance was 3.2 -fold. Each point is the mean of two to six cells, (in $\mathrm{mV})-70(n=$ $6),-55(n=2),-50(n=4),-40(n=2),-30(n=4),-25(n=$ $2),-10(n=4), 5(n=2), 10(n=4), 20(n=2), 30(n=4)$. The bars represent $1 \mathrm{SD}$. The control bathing solution was used to block inhibitory synaptic inputs. NMDA receptors were blocked by including $50 \mu \mathrm{M} \mathrm{AP7}$ in the bath. 


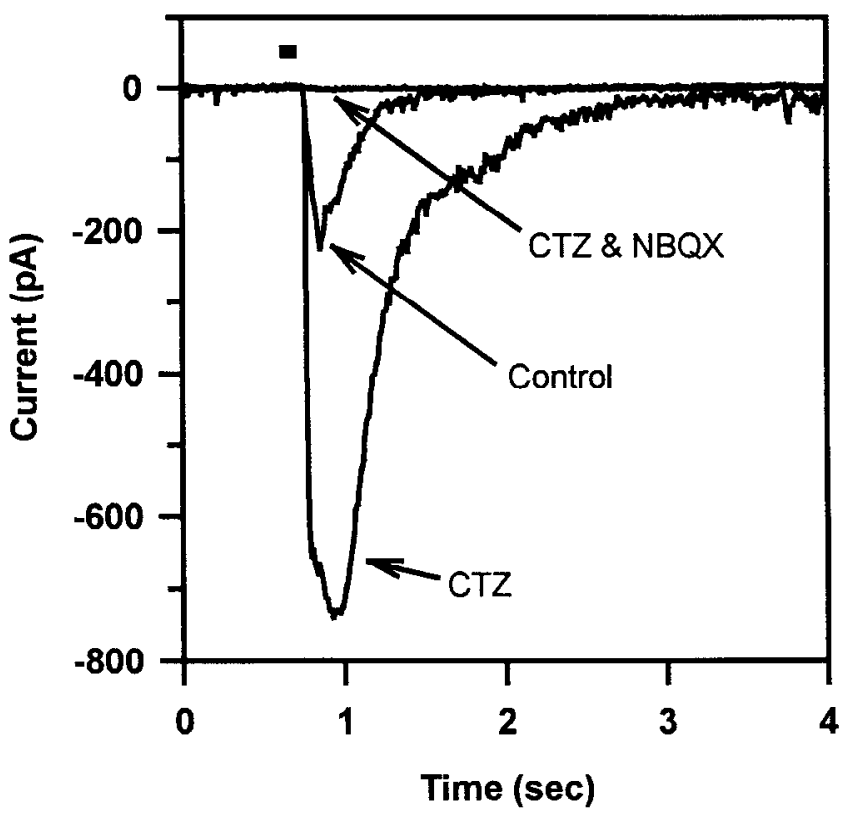

Figure 5. Cyclothiazide-enhanced EPSCs were blocked by an AMPA/ KA receptor antagonist. The AMPA/KA receptor-mediated component of the $\mathrm{K}^{+}$-puff elicited EPSCs was isolated by including $50 \mu \mathrm{M} \mathrm{AP7} \mathrm{in}$ the bath (Control). The EPSCs were enhanced when $30 \mu \mathrm{m}$ cyclothiazide was added to the bath $(C T Z)$. The cyclothiazide-enhanced EPSCs were completely blocked when $10 \mu \mathrm{M}$ NBQX was added to the bath ( $C T Z \& N B Q X$ ). The control bathing solution was used to block inhibitory synaptic inputs. The cell was voltage clamped to $-75 \mathrm{mV}$.

to the OFF pathway, there are no AMPA/KA receptors at the OPL that may also be affected (Nawy and Jahr, 1990; 1991). Figure $8 B$ shows the peak amplitudes of the ON L-EPSCs plotted as a function of membrane potential. The control currentvoltage relationship was relatively linear and reversed polarity near $0 \mathrm{mV}$. Cyclothiazide increased the slope of the currentvoltage relation 3.9 -fold, but it did not significantly affect its shape or reversal potential. The recovery current-voltage relationship was measured after the washout of cyclothiazide, and it was similar to the control relationship.

\section{Discussion}

Cyclothiazide enhanced the response of ganglion cells to glutamatergic agonists, indicating that these cells possess desensitizing, AMPA-preferring glutamate receptors. Cyclothiazide also increased the magnitude and slowed the decay of ganglion cell EPSCs. These results indicate that the kinetics of the synaptic responses of ganglion cells are determined, in part, by desensitizing glutamate receptors.

The mechanism by which cyclothiazide reduces desensitization at AMPA/KA receptors is unclear. Single channel recordings from hippocampal neurons indicated that cyclothiazide acts by prolonging the bursting and increasing the number of AMPAKA channel openings (Yamada and Tang, 1993). It has been hypothesized that the desensitized state of the AMPA/KA receptor is more stable than either the open or closed states and that cyclothiazide potentiates responses by destabilizing the desensitized state (Patneau et al., 1993; Yamada and Tang, 1993).

In our experiments, voltage-gated $\mathrm{Na}^{+}$and $\mathrm{K}^{+}$channels, NMDA, inhibitory GABA and glycine receptors were all pharmacologically blocked, ruling out the involvement of these channels and receptors in the cyclothiazide enhancement of the

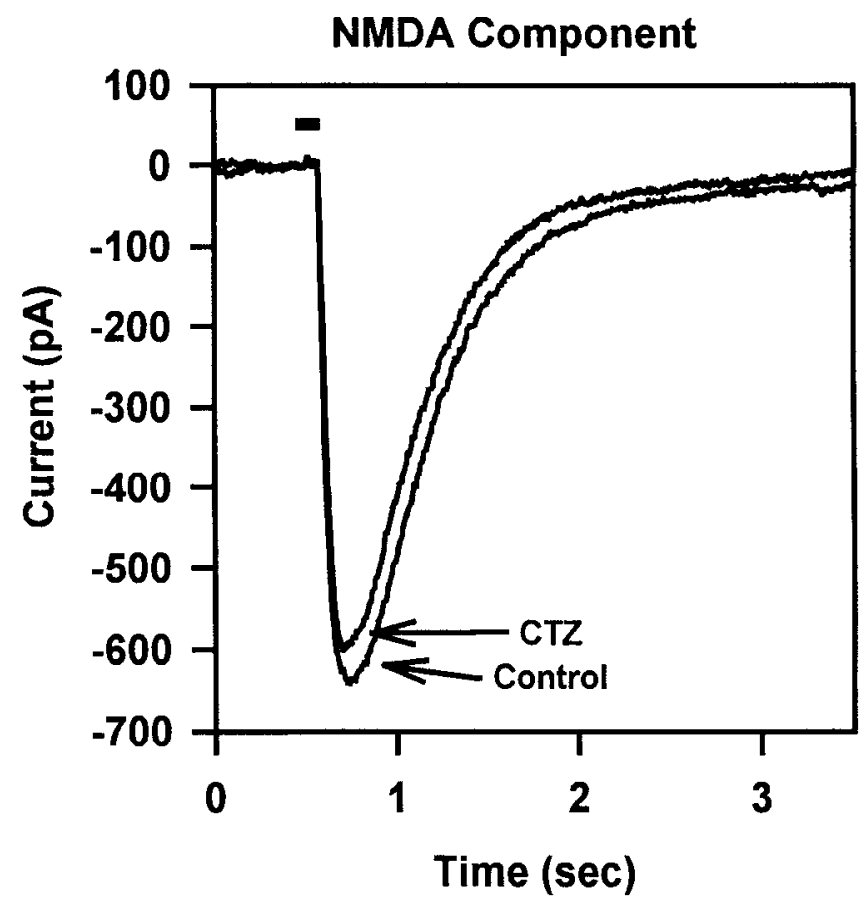

Figure 6. Cyclothiazide did not enhance the NMDA component of the EPSCs. The NMDA component of the EPSC evoked by OPL $\mathrm{K}^{+}$ puffs was isolated by including $10 \mu \mathrm{M}$ NBQX in the bath (Control). Unlike the AMPA/KA receptor-mediated component, the NMDA receptor-mediated component of the EPSC was not enhanced, but slightly reduced from 635 to $600 \mathrm{p} \Lambda$ by $30 \mu \mathrm{M}$ cyclothiazide $(C T Z)$. The bath contained $20 \mu \mathrm{M}$ glycine and no added magnesium. The control bathing solution was used to block inhibitory synaptic inputs. The cell was voltage clamped to $-75 \mathrm{miV}$.

EPSCs. The blockade of GABA- and glycine-mediated synaptic inputs did not affect the contributions of AMPA/KA and NMDA receptor-mediated components of the transient light responses (Mittman et al., 1990). However, we cannot rule out that inhibitory synaptic interactions may play additional roles in shaping transient ganglion cell responses. The use of fluoride as the predominant anion in our intracellular solutions did not affect our results. The synaptic response characteristics of salamander ganglion cells were identical when either chloride, fluoride or sulfate was the predominant intracellular anion (Mittman et al., 1990; Diamond and Copenhagen, 1993; Lukasiewicz and Werblin, 1994). The potentiation by cyclothiazide was not dependent on fluoride because others have reported similar potentiation when either chloride, isethionate, or sulfate was the major intracellular anion (Partin et al., 1993; Trussell et al., 1993; Yamada and Tang, 1993).

\section{Cyclothiazide acts postsynaptically to enhance ganglion cell responses}

The effect of cyclothiazide on ganglion cell synaptic currents evoked by OPL $\mathrm{K}^{+}$puffs was due primarily to an action in the IPL. It might be argued that $\mathrm{K}^{+}$caused release of glutamate from photoreceptors and that a major part of the cyclothiazide effect was on AMPA/KA-mediated responses on bipolar cells. However, the principal effect of $\mathrm{K}^{+}$puff stimuli was to depolarize bipolar cells directly, as shown by the fact that they also evoked excitatory synaptic currents in ganglion cells when AMPA/KA receptors in the OPL were blocked with NBQX. Since there are no NMDA receptors in the salamander OPL (Slaughter and Mil- 
A

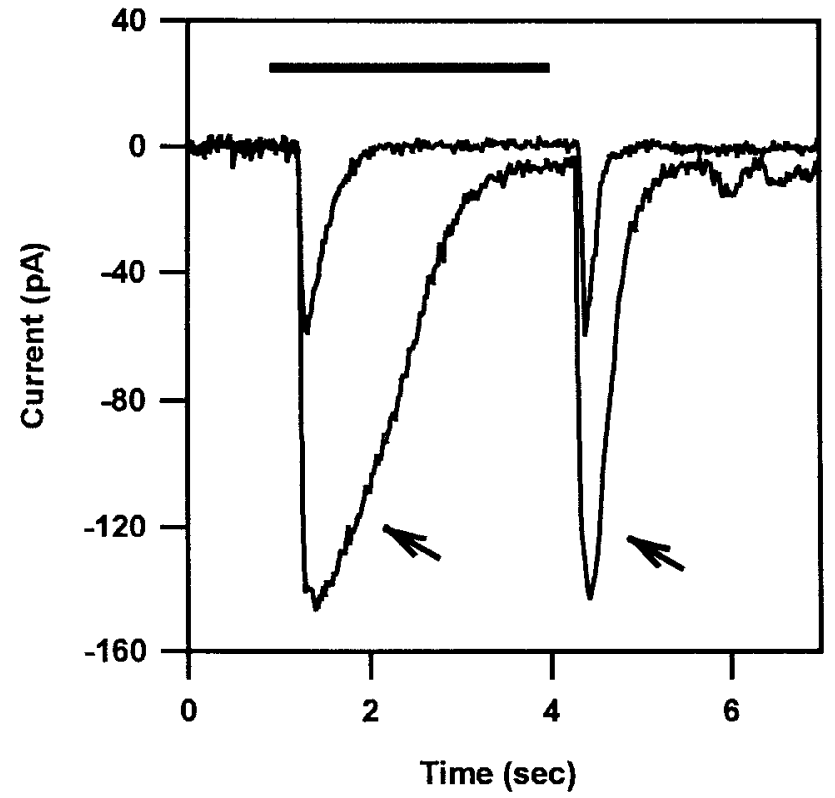

B

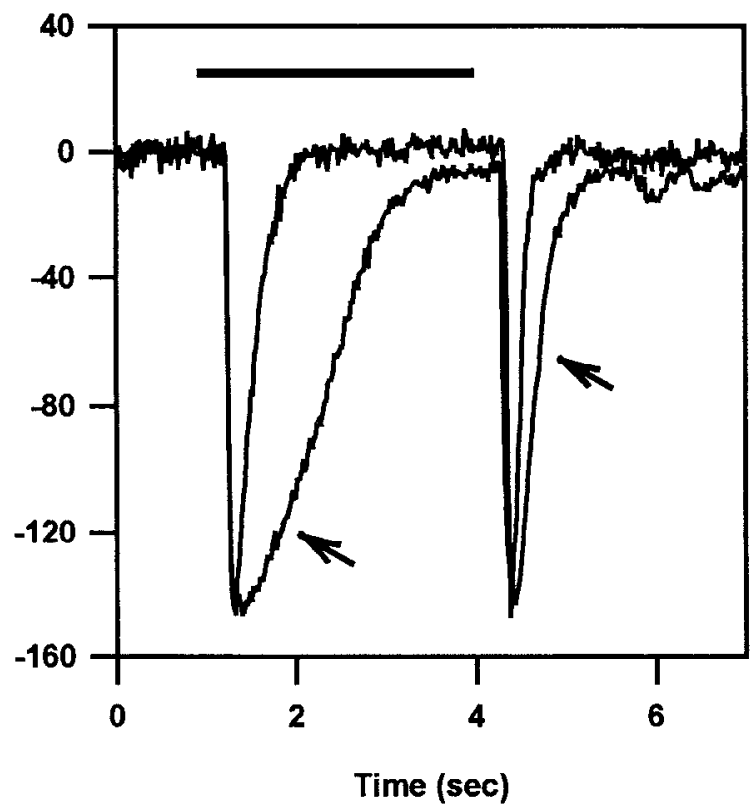

Figure 7. Light-evoked EPSCs were enhanced by cyclothiazide. A, Both the amplitudes and the durations of the ON and OFF transient EPSCs were enhanced by $30 \mu \mathrm{M}$ cyclothiazide (indicated by the arrows). $B$, The control currents were normalized to the peak amplitude of the enhanced currents. The rates of decay for both the ON and the OFF EPSCs were reduced by cyclothiazide. The cell was voltage clamped to $-75 \mathrm{mV}$. The NMDA receptors were blocked by including $30 \mu \mathrm{M}$ AP7 in the bath. The control bathing solution was used to block inhibitory synaptic inputs. The light stimulus was attenuated by $3 \log$ units.

ler, 1983a), this indicates that the major effect of the puffs was not the release of glutamate from photoreceptors which then activated AMPA/KA receptors in the OPL. The NBQX-resistant excitatory currents in ganglion cells were most likely mediated by the NMDA receptors known to be present on ganglion cells. Puffs of L-APB, but not $\mathrm{K}^{+}$, at the OPL elicited outward synaptic currents (due to decreased $\mathrm{ON}$ bipolar transmitter release) in ON or ON-OFF ganglion cells (Lukasiewicz, unpublished observations). This also indicates that the of major effect $\mathrm{K}^{+}$puffs was to depolarize bipolar cells. The lack of enhancement of the NMDA receptor-mediated component of the $\mathrm{K}^{+}$puff-evoked EPSCs in ganglion cells indicated that the EPSCs were not enhanced by cyclothiazide increasing the rate of glutamate release from bipolar cells. This is similar to nucleus magnocellularis synapses where the AMPA/KA, and not the NMDA, component of the synaptic response was selectively enhanced by cyclothiazide (Trussell et al., 1993). Thus, cyclothiazide acted primarily at ganglion cells to enhance EPSCs.

Since there are no AMPA/KA receptors on the dendrites of ON-bipolar cells (Nawy and Jahr, 1990; 1991), we concluded that cyclothiazide also acted at the ON-OFF ganglion cell to enhance the light-evoked ON-EPSCs. Thus several kinds of evidence indicate that cyclothiazide acted postsynaptically at the ganglion cell dendrites. Although there are AMPA/KA receptors in the salamander OPL (Slaughter and Miller, 1983a,b), it is not known if these receptors are sensitive to cyclothiazide. Consequently, we cannot rule out that a component of the cyclothiazide enhancement of light-evoked OFF EPSCs in ON-OFF ganglion cells may have occurred at the OPL.

\section{Depression of light-evoked EPSCs revealed by cyclothiazide}

The amplitude of the control light responses was enhanced by cyclothiazide. The amplitudes of L-EPSCs may have been de- creased if the onset of desensitization was rapid enough to affect the peak amplitude of the synaptic response. The amplitudes of glutamate-evoked currents have been shown to be decreased by rapid desensitization (Trussell et al., 1988). Rapid activation of glutamate receptors was essential for observing the peak response (Trussell et al., 1988; Raman and Trussell, 1992); slower activation resulted in an decreased peak response (Trussell et al., 1988). This suggests that if the rate of glutamate release from bipolar cells was relatively slow, then the peak ganglion cell responses may have been attenuated by desensitization.

An alternative possibility is that the AMPA/KA receptors that mediated the transient L-EPSCs were partially desensitized in the dark. Belgum et al. (1983) showed that mudpuppy ON-OFF ganglion cells receive tonic excitatory synaptic input in the dark. This tonic release of glutamate onto tiger salamander ON-OFF ganglion cells could result in a tonic partial desensitization of AMPA/KA receptors leading to a depression of the L-EPSC amplitudes. Similar results described in the avian nucleus magnocellularis showed that cyclothiazide markedly reduced postsynaptic depression caused by prior activation and desensitization of AMPA/KA receptors (Trussell et al., 1993).

\section{AMPA versus kainate receptors on $O N-O F F$ ganglion cells}

The non-NMDA receptors on dorsal root ganglion neurons are selectively activated by kainate and are sensitive to the lectin, concanavalin A (ConA) but not cyclothiazide (Huettner, 1990; Wong and Mayer, 1993), whereas those on hippocampal neurons are preferentially activated by AMPA and are very sensitive to cyclothiazide, but only weakly sensitive to ConA (Patneau and Mayer, 1990; Wong and Mayer, 1993). When AMPA- and kainate-preferring subunits were expressed in either frog oocytes or human embryonic kidney cells, the responses mediated by 

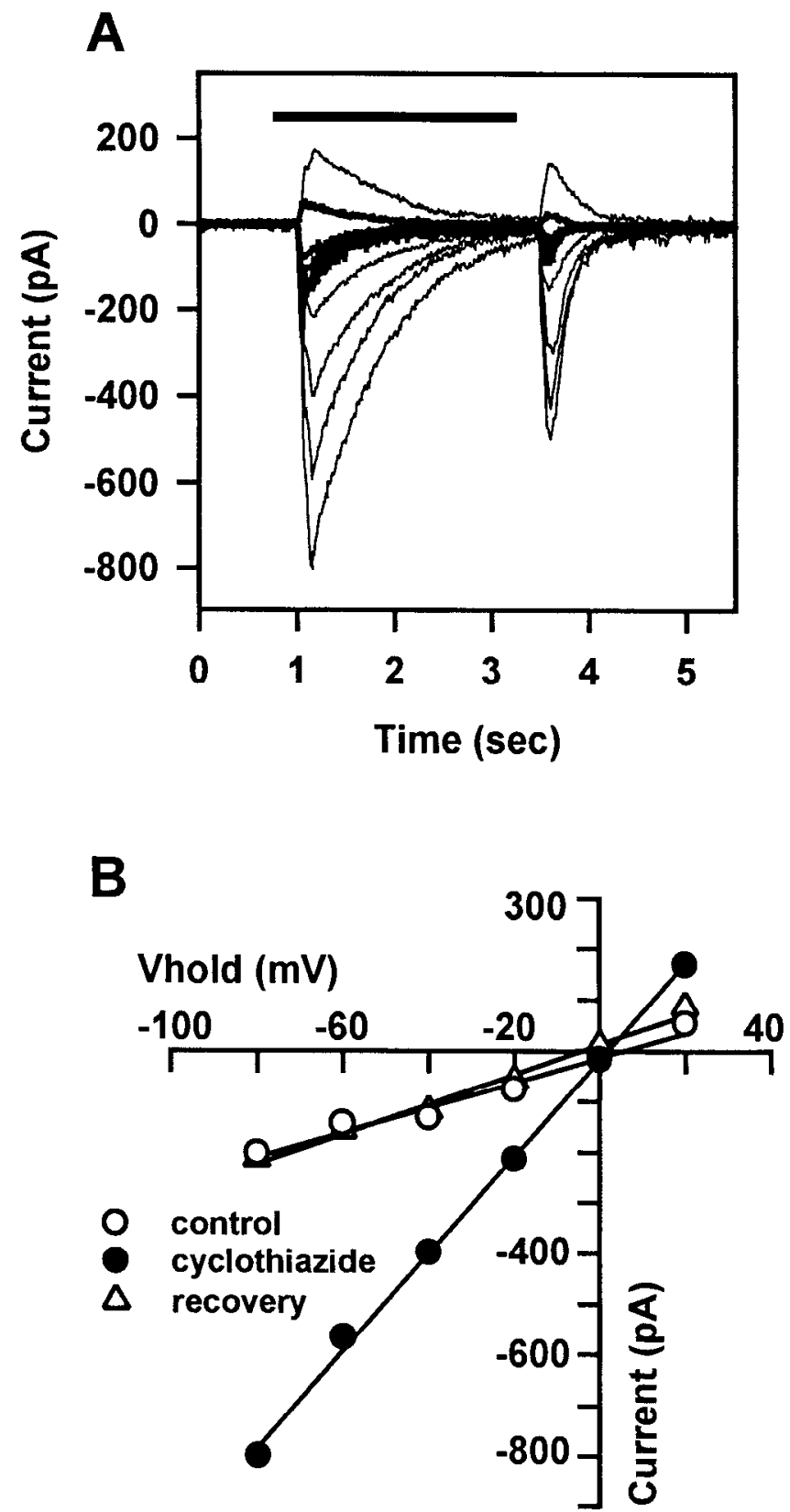

Figure 8. Current-voltage relations for ON and OFF EPSCs measured in the absence and presence of cyclothiazide. A, The largest lightevoked current responses were recorded when the membrane was held at potentials from $-80 \mathrm{mV}$. Each successive response was recorded at a holding potential $20 \mathrm{mV}$ positive to the previous response. The thick traces are the control responses. The thin traces were recorded in the presence of $30 \mu \mathrm{M}$ cyclothiazide. $B$. Peak current responses for the ONEPSC are plotted as a function of membrane potential. Cyclothiazide reversibly enhanced the peak amplitude of the ON EPSC at all holding potentials. The solid lines are the best least squares fits of the data. The slopes of these lines were $2.45 \mathrm{nS}$ for the control responses, $9.54 \mathrm{nS}$ for the responses measured in the presence of cyclothiazide and 2.96 $\mathrm{nS}$ for the recovery responses. The NMDA receptors were blocked by including $50 \mu \mathrm{M}$ AP7 in the bath. The control bathing solution was used to block inhibitory synaptic inputs. The light stimulus was attenuated by $3.4 \log$ units.

AMPA-preferring subunits were strongly potentiated by cyclothiazide but only weakly potentiated by ConA, while the responses mediated by kainate-preferring subunits were enhanced by ConA but not cyclothiazide (Partin et al., 1993). Based on the sensitivity of the ganglion cells to cyclothiazide, it appears that the AMPA-preferring subtype constitutes the major component of the AMPA/KA receptors on ganglion cells.

\section{The formation of transient light responses}

Transient ganglion cell spiking responses to sustained light stimuli were first described by Hartline (1938). Werblin and Dowling (1969) showed that these transient spiking responses were due to transient EPSPs at light onset and offset. Toyoda et al. (1973) and Miller (1979) proposed that the summation of steady ON and OFF bipolar inputs gave rise to the transient, ON-OFF responses recorded in subtypes of amacrine and ganglion cells. Later experiments ruled out this possibility because the OFF response remained transient when the $\mathrm{ON}$ bipolar input was occluded with APB (Slaughter and Miller, 1981). Werblin and colleagues (1988) argued that the transient release of glutamate from bipolar terminals (due to GABAergic feedback) may account for the formation of transient responses in some types of amacrine cells (Maguire et al., 1989). Baclofen mimicked the effects of GABA and suppressed amacrine cell transient responses, suggesting that $\mathrm{GABA}_{\mathrm{B}}$ receptors mediated this feedback (Maguire et al., 1989). However, in ganglion cells (Bai and Slaughter, 1989; Slaughter and Bai, 1989) transient responses appear to be generated by a different mechanism because baclofen enhanced ganglion cell transient responses.

Our results indicate that transient ganglion cell responses are shaped, in part, by desensitizing glutamate receptors. The transient $O N$ and $O F F$ light responses became less transient when the desensitization of AMPA/KA receptors was reduced by cyclothiazide. The effectiveness of cyclothiazide in prolonging transient, light-evoked EPSCs was variable for different ONOFF ganglion cells. In addition, for most ON-OFF ganglion cells, OFF EPSC durations were not enhanced by cyclothiazide to the same extent as ON EPSCs. These variations may reflect different complements of AMPA- and kainate-preferring receptors at the synapses that mediate ON and OFF EPSCs in ONOFF ganglion cells.

Although cyclothiazide prolonged the durations of lightevoked EPSCs in ON-OFF ganglion cells, the enhanced responses remained transient, suggesting that other factors also underlie the formation of these responses. It is unlikely that incomplete blockade of $\mathrm{G} \Lambda \mathrm{B} \Lambda$ receptors on bipolar cell terminals accounts for the remaining transientness because $100 \mu \mathrm{M}$ picrotoxin was to be sufficient to block all of the GABA-mediated synaptic inputs to both ON and OFF bipolar cells (Lukasiewicz and Werblin, 1994) and $150 \mu \mathrm{M}$ picrotoxin completely blocked currents evoked by $1 \mathrm{~mm}$ GABA puffed onto bipolar cell terminals (Lawrence and Lukasiewicz, unpublished observations). Since only glycine and GABA receptors were blocked, we cannot rule out that other transmitters may play a role in the formation of transient responses. Alternatively, the enhanced responses remained transient because the AMPA/KA receptors may possess an AMPA receptor subunit that was a flop splice variant. Responses for flop splice variants have been shown to be less sensitive to cyclothiazide than the flip splice variants (Partin et al., 1993, 1994).

\section{References}

Akaike N, Kaneda M, Hori N, Krishtal OA (1988) Blockade of $N$-methyl-D-aspartate response in enzyme-treated rat hippocampal neurons. Neurosci Lett 87:75-79.

Bai Sun-H, Slaughter MM (1989) Effects of baclofen on transient neu- 
rons in the mudpuppy retina: electrogenic and network actions. J Neurophysiol 61:382-390.

Barnes S, Werblin F (1986) Gated currents generate single spike activity in amacrine cells of the tiger salamander retina. Proc Natl Acad Sci USA 83:1509-1512.

Barnes S, Werblin F (1987) Direct excitatory and lateral inhibitory synaptic inputs to amacrine cells in the tiger salamander retina. Brain Res 406:233-237.

Belgum JH, Dvorak DH, McReynolds JS (1983) Sustained and transient synaptic inputs to on-off ganglion cells in the mudpuppy retina. J Physiol (Lond) 340:599-610.

Belgum JH, Dvorak DR, McReynolds IS (1984) Strychnine blocks transient but not sustained inhibition in mudpuppy retinal ganglion cells. J Physiol (Lond) 354:273-286.

Bettler B, Boulter J, I Iermans-Borgmeyer I, O'Shea-Greenfield A, Deneris ES, Moll C, Borgmeyer U, Hollmann M, Heinemann S (1990) Cloning of a novel glutamate receptor subunit, GluR5: expression in the nervous system during development. Neuron 5:583-595.

Bettler B, Egebjerg J, Sharma G, Pecht G, Hermans-Borgmeyer I, Moll C, Stevens CF, Heinemann S (1992) Cloning of a putative glutamate receptor: a low affinity kainate-binding subunit. Neuron 8:257-265.

Boos R, Muller F, Wassle H (1990) Actions of excitatory amino acids on brisk ganglion cells in the cat retina. J Neurophysiol 64:13681379.

Boulter J, Hollmann M, O'Shea-Greenfield A, Hartley M, Deneris E, Maron C, Heinemann S (1990) Molecular cloning and functional expression of glutamate receptor subunit genes. Science 249:10331037.

Chizhmakov IV, Kiskin NI, Kristal OA, Tsyndrenko AY (1989) Glycine action on $N$-methyl-D-aspartate receptors in rat hippocampal neurons. Neurosci Lett 99:131-136.

Cohen ED, Miller RF (1994) The Role of NMDA and non-NMDA excitatory amino acid receptors in the functional organization of primate retinal ganglion cells. Visual Neurosci 11:317-332.

Coleman PA, Miller RF (1988) Do $N$-methyl-D-aspartate receptors mediate synaptic responses in the mudpuppy retina? J Neurosci 8:47284733.

Diamond JS, Copenhagen DR (1993) The contribution of NMDA and non-NMDA receptors to the light-evoked input-output characteristics of retinal ganglion cells. Neuron 11:725-738.

Donevan SD, Rogawski MA (1993) GYKI 52466, a 2,3-benzodiazepine, is a highly selective, noncompetitive antagonnnist of AMPA/ kainate receptor responses. Neuron 10:51-59.

Egebjerg J, Bettler B, Hermans-Borgmeyer I, Heinemann S (1991) Cloning of a cDN $\wedge$ for a glutamate receptor subunit activated by kainate but not AMPA. Nature 351:745-748.

Famiglietti J, Edward V, Kaneko A, Tachibana M (1977) Neuronal architecture of on and off pathways to ganglion cells in carp retina. Science 198:1267-1269.

Fenwick EM, Marty A, Neher E (1982) A patch-clamp study of bovine chromaffin cells and of their sensitivity to acetylcholine. J Physiol (Lond) 331:577-598.

Forsythe ID, Westhrook (II. (1988) Slow excitatory postsynaptic currents mediated by $N$-methyl-D-asparate receptors on cultured mouse central neurones. J Physiol (Lond) 396:515-533.

Gilbcrtson TA, Borges S, Wilson M (1991) The effects of glycine and GABA on isolated horizontal cells from the salamander retina. J Neurophysiol 66:2002-2013.

Hammill OP, Marty A, Neher E, Sakmann B, Sigworth FJ (1981) Improved patch clamp techniques for high resolution current recording from cells and cell-free patches. Pfluegers Arch 391:85-100.

Hartline HK (1938) The response of single optic nerve fibers of the vertebrate eye to illumination of the retina. Am J Physiol 121:400415

Hestrin S, Nicoll RA, Perkel DJ, Sah P (1990) Analysis of excitatory synaptic action in pyramidal cells using whole-cell recording from rat hippocampal slices. J Physiol (Lond) 422:203-225.

Huettner JE (1990) Glutamate receptor channels in rat DRG neurons: activation by kainate and quisqualate and blockade of desensitization by con A. Neuron 5:255-266.

Kiskin NI, Krishtal OA, Tsyndrenko AY (1986) Excitatory amino acid receptors in hippocampal neurons: kainate fails to desensitize them. Neurosci Lett 63:225-230.

Larson J, Le TT, Hall RA, Lynch G (1994) Effects of cyclothiazide on synaptic responses in slices of adult and neonatal rat hippocampus. Neuroreport 5:389-392.

Lukasiewicz PD, McReynolds JS (1985) Synaptic transmission at $N$-methyl-D-aspartate receptors in the proximal retina of the mudpuppy. J Physiol (Lond) 367:99-115.

Lukasiewicz PD, Roeder RC (1995) Evidence for glycine modulation of excitatory synaptic inputs to retinal ganglion cells. J Neurosci, in press.

Lukasiewicz PD, Werblin FS (1990) The spatial distribution of excitatory and inhibitory inputs to ganglion cell dendrites in the tiger salamander retina. J Neurosci 10:210-221.

Lukasiewicz PD, Werblin FS (1994) A novel GABA receptor modulates synaptic transmission from bipolar to ganglion and amacrine cells in the tiger salamander retina. J Neurosci 14:1213-1223.

Maguire G, Lukasiewicz P, Werblin F (1989) Amacrine cell interactions underlying the response to change in the tiger salamander retina. J Neurosci 9:726-735.

Massey SC, Miller RF (1988) Glutamate receptors of ganglion cells in the rabbit retina: evidence for glutamate as a bipolar cell transmitter J Physiol (Lond) 405:635-655.

Massey SC, Miller RF (1990) N-Methyl-D-aspartate receptors of ganglion cells in rabbit retina. J Neurophysiol 63:16-30.

Mayer ML, Vyklicky J Ladislav (1989) Concanavalin A selectively reduces desensitization of mammalian neuronal quisqualate receptors. Proc Natl Acad Sci USA 86:1411-1415.

Miller RF (1979) The neuronal basis of ganglion cell receptive field organization and the physiology of amacrine cells. In: The neurosciences fourth study guide (Schmitt FO, Worden FG, eds), pp 227245. Cambridge, MA: MIT Press.

Mittman S, Taylor WR, Copenhagen DR (1990) Concomitant activation of two types of glutamate receptor mediates excitation of salamander retinal ganglion cells. J Physiol (Lond) 428:175-197.

Nawy S, Jahr CE (1990) Suppression by glutamate of cGMP-activated conductance in retinal bipolar cells. Nature 346:269 271 .

Nawy S, Jahr CE (1991) cGMP-gated conductance in retinal bipolar cells is suppressed by the photoreceptor transmitter. Neuron 7:677683.

Nelson R, Famiglietti JEV, Kolb H (1978) Intracellular staining reveals different levels of stratification for on- and off-center ganglion cells in cat retina. J Neurophysiol 41:472-483.

O'Dell TJ, Christensen BN (1989) A voltage-clamp study of isolated stingray horizontal cell non-NMDA excitatory amino acid receptors. J Neurophysiol 61:162-172.

Partin KM, Patneau DK, Winters CA, Mayer ML, Buonanno A (1993) Selective modulation of desensitization at AMPA versus kainate receptors by cylcothiazide and concanavalin A. Neuron 11:1069-1082.

Partin KM, Patneau DK, Mayer ML (1994) Cyclothiazide differentially modulates desensitization of alpha-amino-3-hydroxy-5-methyl-4 isoxazolepropionic acid receptor splice variants. Mol Pharmacol 46 $129-138$

Patneau DK, Mayer ML (1990) Structure-activity relationships for amino acid transmitter candidates acting at $N$-methyl-D-aspartate and quisqualate receptors. J Neurosci 10:2385-2399.

Patneau DK, Vyklicky LJ, Mayer ML (1993) Hippocampal neurons exhibit cyclothiazide-sensitive rapidly desensitizing responses to kainate. J Neurosci 13:1-22.

Pelletier MR, Hablitz JJ (1994) Altered desensitization produces enhancement of epsps in neocortical neurons. J Neurophysiol 72:10321036.

Raman IM, Trussell LO (1992) The kinetics of the response to glutamate and kainate in neurons of the avian cochlear nucleus. Neuron 9:173-186.

Rammes G, Parsons C, Muller W, Swandulla D (1994) Modulation of fast excitatory synaptic transmission by cyclothiazide and gyki 52466 in the rat hippocampus. Neurosci Lett 175:21-24.

Slaughter MM, Bai S-H (1989) Differential effects of baclofen on sustained and transient cells in the mudpuppy retina. J Neurophysiol 61 374-381.

Slaughter MM, Miller RF (1981) 2-Amino-4-phosphonobutyric acid: a new pharmacological tool for retina research. Science 211:182-185.

Slaughter MM, Miller RF (1983a) An excitatory amino acid antagonist blocks cone input to sign-conserving second-order retinal neurons. Science 219:1230-1232.

Slaughter MM, Miller RF (1983b) The role of excitatory amino acid 
transmitters in the mudpuppy retina: an analysis with kainic acid and $N$-methyl aspartate. J Neurosci 3:1701-1711.

Sommer B, Seeburg PH (1992) Glutamate receptor channels: novel properties and new clones. Trends Pharmacol Sci 13:291-296.

Tang Cha-M, Dichter M, Morad M (1989) Quisqualate activates a rapidly inactivating high conductance ionic channel in hippocampal neurons. Science 243:1474-1477.

Thio LL, Clifford DB, Zorumski CF (1991) Characterization of quisqualate receptor desensitization in cultured postnatal rat hippocampal neurons. J Neurosci 1 1:3430-3441

Toyoda Jun-I, Hashimoto H, Ohtsu K (1973) Bipolar-amacrine transmission in the carp retina. Vision Res 13:295-307.

Trussell LO, Thio LL, Zorumski CF, Fischbach GD (1988) Rapid desensitization of glutamate receptors in vertebrate central neurons. Proc Natl Acad Sci USA 85:2834-2838.

Trussell LO, Zhang S, Raman IM (1993) Desensitization of AMPA receptors upon multiquantal release. Neuron 10:1185-1196.

Werblin FS (1978) Transmission along and between rods in the tiger salamander retina. J Physiol (Lond) 280:449-470.

Werblin FS, Dowling JE (1969) Organization of the retina of mudpup- py, Necuturus maculosis. II. Intracellular recording. J Neurophysiol $32: 331-355$

Werblin F, MacGuire G, Lukasiewicz P, Eliasof S, Wu SM (1988) Neural interactions mediating the detection of motion in the retina of the tiger salamander. Visual Neurosci 1:317-329.

Werner P, Voigt M, Keinanen K, Wisden W, Seeburg PH (1991) Cloning of a putative high-affinity kainate receptor expressed predominantly in hippocampal CA3 cells. Nature 351:742-744.

Wong LA, Mayer ML (1993) Differential modulation by cyclothiazide and concanavalin $\mathrm{A}$ of desensitization at native $\alpha$-amino-3-hydroxy5-methyl-4-isoxazolepropionic acid- and kainate-preferring glutamate receptors. Mol Pharmacol 44:504-510.

Yamada KA, Rothman SM (1992) Diazoxide blocks glutamate desensitization and prolongs excitatory postsynaptic currents in rat hippocampal neurons. J Physiol (Lond) 458:409-423.

Yamada KA, Tang C-M (1993) Benzothiadiazides inhibil rapid glutamate receptor desensitization and enhance glutamatergic synaptic currents. J Neurosci 13:3904-3915.

Zorumski CF, Yamada KA, Price MT, Olney JW (1993) A benzodiazepine recognition site associated with the non-NMDA glutamate receptor. Neuron 10:61-67. 